\title{
Rapid Mobilization of Noncrystalline U(IV) Coupled with FeS Oxidation
}

\author{
Yuqiang Bi, ${ }^{\dagger}$ Malgorzata Stylo, ${ }^{\ddagger}$ Rizlan Bernier-Latmani, ${ }^{\dagger}$ and Kim F. Hayes ${ }^{*}{ }^{\dagger}$ \\ ${ }^{\dagger}$ Civil and Environmental Engineering, University of Michigan, Ann Arbor, Michigan 48109, United States \\ ${ }^{\ddagger}$ Environmental Microbiology Laboratory, Ecole Polytechnique Fédérale de Lausanne, CH-1015 Lausanne, Switzerland
}

\author{
Supporting Information
}

ABSTRACT: The reactivity of disordered, noncrystalline U(IV) species remains poorly characterized despite their prevalence in biostimulated sediments. Because of the lack of crystalline structure, noncrystalline U(IV) may be susceptible to oxidative mobilization under oxic conditions. The present study investigated the mechanism and rate of oxidation of biogenic noncrystalline U(IV) by dissolved oxygen (DO) in the presence of mackinawite $(\mathrm{FeS})$. Previously recognized as an effective reductant and oxygen scavenger, nanoparticulate $\mathrm{FeS}$ was evaluated for its role in influencing $\mathrm{U}$ release in a flowthrough system as a function of $\mathrm{pH}$ and carbonate concentration. The results demonstrated that noncrystalline

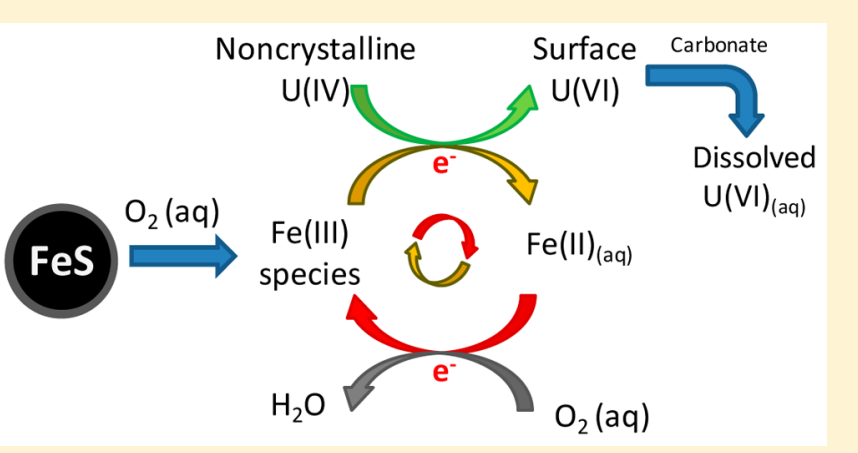
$\mathrm{U}(\mathrm{IV})$ was more susceptible to oxidation than uraninite $\left(\mathrm{UO}_{2}\right)$ in the presence of dissolved carbonate. A rapid release of $\mathrm{U}$ occurred immediately after $\mathrm{FeS}$ addition without exhibiting a temporary inhibition stage, as was observed during the oxidation of $\mathrm{UO}_{2}$, although FeS still kept DO levels low. X-ray photoelectron spectroscopy (XPS) characterized a transient surface Fe(III) species during the initial FeS oxidation, which was likely responsible for oxidizing noncrystalline U(IV) in addition to oxygen. In the absence of carbonate, however, the release of dissolved $U$ was significantly hindered as a result of $U$ adsorption by FeS oxidation products. This study illustrates the strong interactions between iron sulfide and U(IV) species during redox transformation and implies the lability of biogenic noncrystalline U(IV) species in the subsurface environment when subjected to redox cycling events.

\section{INTRODUCTION}

Decades after the end of active uranium mining, milling, and processing, uranium contamination in the subsurface environment remains problematic and represents a public health threat across the United States. Given that $\mathrm{U}$ mobility is strongly related to its oxidation state, ${ }^{1}$ the transformation of soluble and mobile $\mathrm{U}(\mathrm{VI})$ to reduced and relatively immobile $\mathrm{U}(\mathrm{IV})$ is a desirable strategy for effective in situ $U$ remediation. ${ }^{2-4}$ Until recently, the sparingly soluble uraninite mineral $\left(\mathrm{UO}_{2(\mathrm{~s})}\right)$ was considered to be the sole product of $\mathrm{U}(\mathrm{VI})$ reduction. ${ }^{1,5,6}$ An increasing number of studies have revealed the existence of disordered, noncrystalline $\mathrm{U}(\mathrm{IV})$ species, which are characterized by the absence of U-U pair backscattering at $3.8 \AA$ in X-ray absorption spectroscopy (XAS) data. $^{7-9}$ Both laboratory $^{8-10}$ and field ${ }^{11-14}$ research suggest the prevalence of this $\mathrm{U}(\mathrm{IV})$ species as a result of association of U(IV) with EPS from biofilms after active $U$ bioremediation. Unfortunately, limited thermodynamic and structural information on noncrystalline $\mathrm{U}(\mathrm{IV})$ is available, ${ }^{7,15}$ rendering the current geochemical models insufficient for evaluating $U$ stability and optimal conditions for cleanup efforts.

Because of the lack of crystalline structure, noncrystalline $\mathrm{U}(\mathrm{IV})$ is likely more labile and susceptible to reoxidation and complexation than $\mathrm{UO}_{2}$ in subsurface environments. Only a few studies, however, have examined the reactivity of biogenic noncrystalline U(IV) in laboratory systems. ${ }^{16,17}$ Alessi et al. ${ }^{16}$ showed that the noncrystalline U(IV) fraction can be selectively extracted from a $\mathrm{U}(\mathrm{IV})-\mathrm{U}(\mathrm{VI})$ mixture by an anoxic $1 \mathrm{M}$ bicarbonate solution. Cerrato et al. ${ }^{17}$ further demonstrated that the $\mathrm{U}(\mathrm{IV})$ species can be readily oxidized by dissolved oxygen (DO) and persulfate. In a heterogeneous subsurface environment, various complexing ligands (i.e., carbonate) and oxidants (i.e., oxygen and $\mathrm{Fe}(\mathrm{III})$ ) for $\mathrm{U}(\mathrm{IV})$ are usually concurrently present, which may cause fast remobilization of $U$ if oxidants reenter bioreduction zones once electron-donor additions cease. However, natural reductants present, such as reduced minerals and biomass, may enhance the longevity of noncrystalline $\mathrm{U}(\mathrm{IV})$ against oxidation by scavenging oxidants. It is therefore critical to understand the reactivity of noncrystalline U(IV) and its potential mobilization pathways during redox transitions under environmentally relevant conditions.

During reductive bioremediation, iron sulfide minerals (e.g., mackinawite; hereafter referred as FeS) are commonly reported

Received: September 3, 2015

Revised: November 24, 2015

Accepted: December 22, 2015

Published: December 22, 2015 
by-products along with U(IV) precipitates. $^{11,18,19}$ Previous studies have conclusively demonstrated that $\mathrm{FeS}$ is capable of both reducing uranyl ion ${ }^{20,21}$ and inhibiting $\mathrm{UO}_{2}$ oxidative dissolution by scavenging DO. ${ }^{22,23}$ Field studies attributed the retardation of $U$ mobilization to sulfide minerals formed in the subsurface environment. ${ }^{18,24}$ Because $\mathrm{FeS}$ was also found in close association with noncrystalline $\mathrm{U}(\mathrm{IV})$ in biostimulated aquifers, ${ }^{11}$ the protection of the $\mathrm{U}(\mathrm{IV})$ species against oxidation was expected. However, given the lability of noncrystalline $\mathrm{U}(\mathrm{IV}){ }^{16,17}$ it is unclear whether oxygen will preferentially react with $\mathrm{FeS}$ to limit the oxidative mobilization of this $\mathrm{U}(\mathrm{IV})$ species. In addition, because $\mathrm{FeS}$ oxidation by oxygen generates a number of $\mathrm{Fe}$ (III) products, the newly formed $\mathrm{Fe}$ (III) species may act as additional oxidants to cause U(IV) oxidation and mobilization. Although $\mathrm{Fe}$ (III) products were not observed to oxidize $\mathrm{UO}_{2}$ during $\mathrm{FeS}$ oxidation, ${ }^{25}$ the thermodynamic favorability may be shifted toward the oxidation of noncrystalline U(IV). ${ }^{26,27}$ The role of FeS in influencing the stability of noncrystalline U(IV) can therefore be different from that of $\mathrm{UO}_{2}$.

The objective of this study was to determine the effect of FeS on the oxidative mobilization of noncrystalline U(IV) under relevant oxic groundwater conditions controlled by the introduction of DO. Biomass-associated noncrystalline U(IV) suspensions were prepared in a medium that suppressed $\mathrm{UO}_{2}$ formation. Laboratory flow-through experiments were conducted to investigate the change of $U$ and $\mathrm{Fe}$ speciation as a function of carbonate concentration and solution $\mathrm{pH}$. Surfacesensitive X-ray photoelectron spectroscopy (XPS) was employed to characterize intermediate $U$ and $\mathrm{Fe}$ oxidation products. The amount of $U$ release versus time was also determined to obtain $\mathrm{U}$ oxidation rate, which was compared with that of $\mathrm{UO}_{2}$ under similar experimental conditions. The results obtained from this study contribute to a fundamental understanding of the reactivity of noncrystalline U(IV) species and their resistance to reoxidation in natural and bioremediated sediments.

\section{MATERIALS AND METHODS}

Synthesis of Mackinawite and Noncrystalline U(IV). Mackinawite was synthesized by mixing $1.1 \mathrm{M} \mathrm{Na}_{2} \mathrm{~S}$ solution with $0.57 \mathrm{M} \mathrm{FeCl}_{2}$ solution $(\mathrm{S}: \mathrm{Fe} \approx 1.93)$ inside an anaerobic chamber with a gas composition of $\sim 5 \% \mathrm{H}_{2}$ in $\mathrm{N}_{2}{ }^{22}$ The precipitate was allowed to age for 3 days under constant stirring before being rinsed with deoxygenated DI water. The final product was freeze-dried under a vacuum and stored in capped glass vials inside the anaerobic chamber until use. The resulting mackinawite was characterized as nanocrystalline particles with mineralogical description as detailed in Jeong et al. ${ }^{28}$

Biomass-associated noncrystalline U(IV) was produced as previously described in Bernier-Latmani et al. ${ }^{7}$ Briefly, Shewanella oneidensis MR-1 cultures were grown anaerobically in sterile Luria-Bertani (LB) medium and harvested when they reached mid-exponential phase. Cells were harvested by centrifugation at $8000 \mathrm{~g}$ for $10 \mathrm{~min}$ and washed in simple BP medium, composed of $30 \mathrm{mM} \mathrm{NaHCO}$ and $20 \mathrm{mM} \mathrm{1,4-}$ piperazinediethanesulfonic acid (PIPES buffer) adjusted to $\mathrm{pH}$ 6.8. The reduction assay was initiated inside an anaerobic chamber by resuspending the washed cells in Widdel low phosphate (WLP) basal medium to an $\mathrm{OD}_{600}$ of 1 and amending it with $20 \mathrm{mM}$ lactic acid and $1 \mathrm{mM}$ uranyl acetate (Table S1). Subsamples of the suspension were collected and filtered, and the filtrate was analyzed by ICP-MS to confirm the complete removal of $\mathrm{U}(\mathrm{VI})$ in the aqueous phase. The cell suspensions were then collected by centrifugation, resuspended in a small volume of anoxic water, placed in serum bottles with a $\mathrm{N}_{2}$ headspace, sealed within Mylar bags purged with $\mathrm{N}_{2}$, and shipped from École Polytechnique Fédérale de Lausanne to the University of Michigan using an overnight delivery service. Characterization of this material by TEM and XAS confirmed that the reduced $\mathrm{U}(\mathrm{IV})$ was primarily in a form of noncrystalline U(IV) (Figure S1).

Oxidation of Noncrystalline $\mathrm{U}(\mathrm{IV})$ in Flow-Through Systems. The oxic flow-through experiments were conducted with $50 \mathrm{~mL}$ continuously stirred tank reactors (CSTRs) (Figure S2) using an initial $\sim 0.46 \mathrm{mM}$ noncrystalline $\mathrm{U}(\mathrm{IV})$. At the beginning of an experiment, $4.8 \mathrm{mM} \mathrm{FeS}(0.43 \mathrm{~g} / \mathrm{L})$ was added to the CSTR reactor in an anaerobic chamber to provide a FeS:U(IV) molar ratio of $\sim 10$, representing a lower-end ratio in the field. ${ }^{11}$ An influent solution containing varing concentrations of $\mathrm{NaHCO}_{3}, \mathrm{KCl}$, and $\mathrm{CaCl}_{2}$ was prepared and constantly purged with an $\mathrm{O}_{2} / \mathrm{CO}_{2} / \mathrm{N}_{2}$ gas mixture to obtain the desired $\mathrm{pH}$, dissolved oxygen (DO), and total inorganic carbonate (DIC) concentrations (Table S2). To study the impact of carbonate on noncrystalline $\mathrm{U}(\mathrm{IV})$ oxidation, we varied both $\mathrm{NaHCO}_{3}$ concentration and $P_{\mathrm{CO}_{2}}$ in the gas mixture while keeping the solution $\mathrm{pH}$ constant at $7.0 \pm 0.1$. For the experiments without carbonate, $10 \mathrm{mM} \mathrm{3-}$ $\left(N\right.$-morpholino) propanesulfonic acid (MOPS, $\left.\mathrm{p} K_{\mathrm{a}}=7.2\right)$ was used to buffer $\mathrm{pH}$ at 7.0. The resulting influent DIC concentration ranged from 0 to $10.8 \mathrm{mM}$. The oxic influent $\left(\sim 1.8 \mathrm{mg} \cdot \mathrm{L}^{-1} \mathrm{DO}\right)$ was delivered to the reactors by a peristaltic pump at a rate of $1.8-2.0 \mathrm{~mL} \cdot \mathrm{min}^{-1}$ until complete $\mathrm{FeS}$ oxidation had occurred. Effluent DO, pH, and Eh were constantly monitored to track the process of $\mathrm{FeS}$ oxidation. All oxic flow-through experiments were operated outside the anaerobic chamber at room temperature $\left(23 \pm 1{ }^{\circ} \mathrm{C}\right)$ and covered by aluminum foil to avoid light exposure. Control experiments of noncrystalline $\mathrm{U}(\mathrm{IV})$ oxidation in the absence of $\mathrm{FeS}$ were conducted under otherwise identical experimental conditions. To determine the oxidation rate of noncrystalline U(IV) under anoxic conditions, we operated the entire flowthrough system in an anaerobic chamber in the presence and absence of FeS. The influent solution was prepared with deoxygenated DI water and purged with oxygen-free gas to ensure consistently anoxic conditions $\left(<0.1 \mathrm{mg} \cdot \mathrm{L}^{-1} \mathrm{DO}\right)$.

To test the role of $\mathrm{FeS}$ oxidation products on noncrystalline $\mathrm{U}(\mathrm{IV})$ mobilization, we conducted flow-through experiments at both acidic (5.4) and basic (9.0) pH values. Previous studies demonstrated that $\mathrm{FeS}$ oxidized through $\mathrm{pH}$-dependent reaction pathways: proton-promoted solution-phase oxidation at acidic $\mathrm{pH}$ and surface-mediated oxidation at basic $\mathrm{pH}^{23,29}$ Distinct intermediate $\mathrm{Fe}$ (III) products may be generated at different $\mathrm{pH}$ values, ${ }^{29}$ affecting the stability of noncrystalline $\mathrm{U}(\mathrm{IV})$ through redox reactions. Influent chemical compositions were modified for basic $\mathrm{pH}$ experiments (Table S2) to maintain DIC concentrations at $\sim 1 \mathrm{mM}$ and prevent calcite precipitation.

To test the effect of aging of $\mathrm{FeS}$ oxidation products, we used two types of model compounds for the flow-through experiments. We synthesized two-line ferrihydrite $(5.1 \mathrm{mM}$ total $\mathrm{Fe}$ ) according to Schwertmann and $\mathrm{Cornell}^{30}$ to represent an early-stage $\mathrm{FeS}$ oxidation model product that could potentially oxidize noncrystalline U(IV). A Fe(III) solid mix was also prepared by oxidizing $\mathrm{FeS}$ in a batch reactor with 

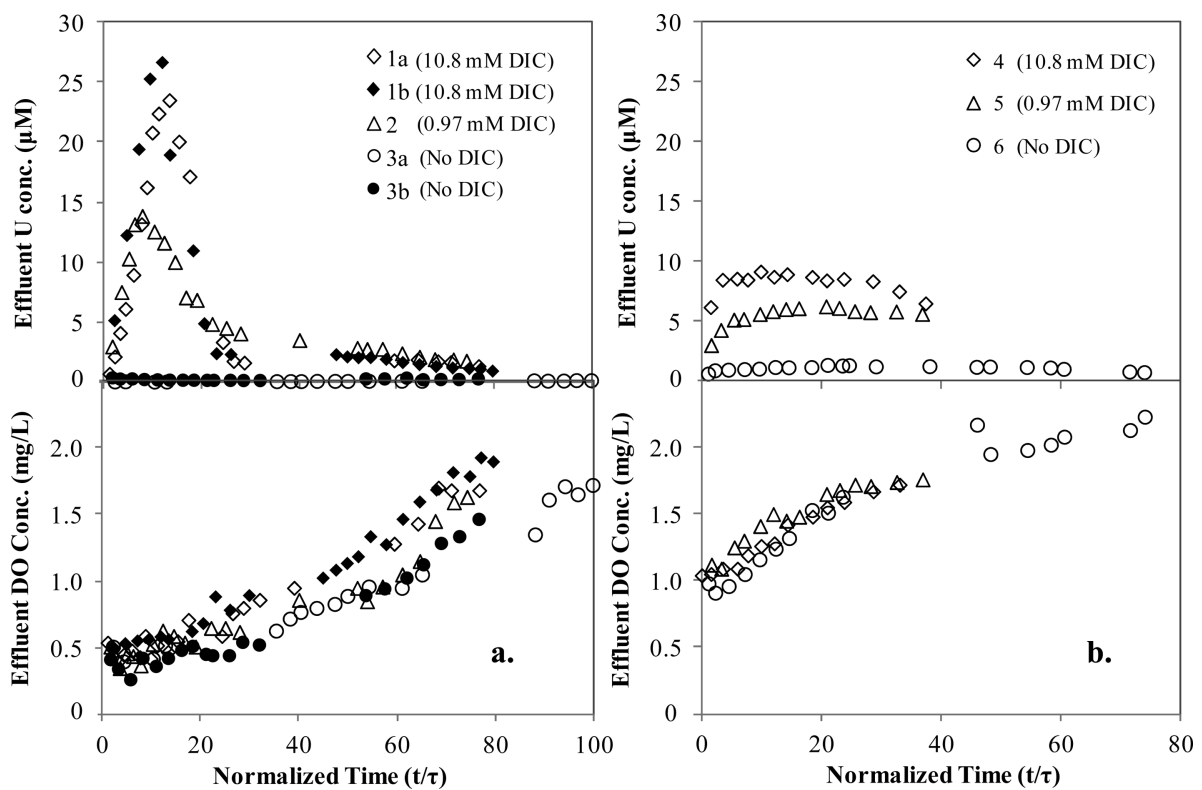

Figure 1. Total dissolved $\mathrm{U}$ and dissolved oxygen (DO) concentration profiles as a function of time during the oxidative mobilization of $\sim 0.47 \mathrm{mM}$ noncrystalline U(IV) in the presence (a) and absence (b) of $4.8 \mathrm{mM}$ FeS. Replicates are represented by the filled vs open symbols. Influent solution condition: $0.4 \mathrm{mM} \mathrm{KCl}$, and $2.0 \mathrm{mM} \mathrm{CaCl}, 1.8 \mathrm{mg} \cdot \mathrm{L}^{-1}$ influent $\mathrm{DO}$, and $\mathrm{pH}$ 7.0.

oxygen to represent the aged $\mathrm{Fe}(\mathrm{III})$ products. The matrix (4.4 $\mathrm{mM}$ total $\mathrm{Fe}$ ) was previously characterized to consist of goethite, lepidocrocite, and elemental sulfur. ${ }^{22}$

Analyses. Total dissolved $\mathrm{Fe}$ and $\mathrm{U}$ were determined in effluent samples by ICP-MS (Agilent 7900). The detection limits for $\mathrm{U}$ and $\mathrm{Fe}$ were 0.01 and $0.1 \mu \mathrm{g} \cdot \mathrm{L}^{-1}$, respectively. Dissolved $\mathrm{Fe}(\mathrm{II})$ was determined photometrically by the ferrozine method at $562 \mathrm{~nm}$ using a UV/vis spectrophotometer (Varian Cary 3E). The dissolved Fe(II) equaled total dissolved $\mathrm{Fe}$ measured by ICP-MS within 5\% error. Because aqueous sulfide, thiosulfate, and sulfate were previously determined to be negligible during the abiotic oxidation reaction, ${ }^{22,23}$ these sulfur species were not measured in the present study.

In selected flow-through experiments, solid suspensions were collected at various time points for analyzing the change of oxidation state and stoichiometry of U. The CSTR reactor was quickly transferred to the anaerobic chamber, where a $1-2 \mathrm{~mL}$ suspension sample was taken. The flow was briefly interrupted for less than $5 \mathrm{~min}$ before the oxidation reaction was resumed. The solid samples were then characterized by XPS at the University of Michigan Electron Microbeam Analysis Laboratory (EMAL). Briefly, wet pastes obtained after filtering through a $0.1 \mu \mathrm{m}$ nylon membrane were dried in the anaerobic chamber and mounted on double-sided $\mathrm{Cu}$ tape. The samples, kept inside airtight containers, were transferred to the XPS chamber. XPS spectra were collected on a Kratos Axis Ultra XPS using a monochromated $\mathrm{Al}-\mathrm{K}_{\alpha} \mathrm{X}$-ray source $(1486 \mathrm{eV})$. Region scans were obtained for $U$ 4 f peaks, Fe $2 p_{3 / 2}$, and $S 2 p$, with the energy calibrated to adventitious $\mathrm{C} 1 \mathrm{~s}$ at a binding energy of $284.5 \mathrm{eV}$. Spectra were best fit by nonlinear leastsquares with a Gaussian-Lorentzian peak using the CasaXPS curve resolution software. Mass balance of $U$ was checked at the end of the experimental run for selected samples. To do this, when the experiment was completed, we digested solid samples in CSTR in concentrated nitric acid to determine solidbound $U$ concentration and added to the total amount that had exited the reactor.
Oxidation Rate Calculations. When noncrystalline U(IV) was rapidly oxidized by $\mathrm{DO}$, effluent $U$ concentration versus time profiles displayed a sharp $U$ peak without reaching steady state. The oxidation rate was estimated by the amount of total $\mathrm{U}$ released into the effluent within a given time. The cumulative total $U$ release was based on measured $U$ concentration and flow rate and was plotted against reaction time (Figure S3). The oxidation rates $R_{\mathrm{n}}\left(\mathrm{mol} \cdot \mathrm{mol} \mathrm{U}(\mathrm{IV})^{-1} \cdot \mathrm{s}^{-1}\right)$ for noncrystalline $U(I V)$ were obtained by subjecting the initial linear portion of the plots to regression analysis, followed by a normalization with respect to the total mole of noncrystalline U(IV). Because the noncrystalline U(IV) had an unclear chemical composition and structure, molar concentration was used for rate calculation instead of mass concentration. For the rate analysis, typically more than seven points were utilized, resulting in $R^{2}$ values greater than 0.98 for all least-squares fits. Because noncrystalline $\mathrm{U}(\mathrm{IV})$ may contain up to $10 \% \mathrm{U}(\mathrm{VI})$ as estimated by XPS, the potential contribution of $\mathrm{U}(\mathrm{VI})$ to the overall $\mathrm{U}$ release was subtracted from initial rates described above. The influence of $\mathrm{U}(\mathrm{VI})$ component on the oxidation rates was reflected in the error bar: the upper limit showed the oxidation rate of noncrystalline $\mathrm{U}(\mathrm{IV})$ without any $\mathrm{U}(\mathrm{VI})$ impurity, while the lower limit showed the rate with $10 \% \mathrm{U}(\mathrm{VI})$ impurity.

In cases in which a steady-state effluent $U$ concentration was established relatively quickly after an initial reactor start-up, the oxidation rate of noncrystalline $\mathrm{U}(\mathrm{IV})\left(R_{\mathrm{n}}\right)$ was calculated using the following eq (eq 1 ):

$$
R_{\mathrm{n}}=\frac{[\mathrm{U}]_{\mathrm{ss}} \times Q}{V \times\left[\mathrm{U}(\mathrm{IV})_{\text {noncrystalline }}\right]}
$$

where $R_{\mathrm{n}}\left(\mathrm{mol} \cdot \mathrm{mol} \mathrm{U}(\mathrm{IV})^{-1} \cdot \mathrm{s}^{-1}\right)$ is mass-normalized oxidation rate of noncrystalline $\mathrm{U}(\mathrm{IV}), \mathrm{Q}\left(\mathrm{L} \cdot \mathrm{s}^{-1}\right)$ the flow rate, $V(\mathrm{~L})$ the reactor volume, $[\mathrm{U}]_{\mathrm{ss}}\left(\mathrm{mol} \cdot \mathrm{L}^{-1}\right)$ the steady-state concentration of total dissolved $\mathrm{U}$, and $\left[\mathrm{U}(\mathrm{IV})_{\text {noncrystalline }}\right]\left(\mathrm{mol} \mathrm{U}(\mathrm{IV}) \cdot \mathrm{L}^{-1}\right)$ the molar concentration of noncrystalline $U(I V)$ in the reactor. The $[\mathrm{U}]_{\mathrm{ss}}$ was typically the average of the values from periods of 10 or more residence times, over which the effluent $U$ 
Table 1. Experimental Mole-Normalized Oxidation Rates $\left(R_{n}\right)$ of Noncrystalline U(IV) Obtained under Various Combinations of Oxidizing Conditions and Water Compositions

\begin{tabular}{|c|c|c|c|c|c|c|c|c|}
\hline experimental ID & $\begin{array}{c}\text { [noncrystalline } \mathrm{U}(\mathrm{IV})] \\
(\mathrm{mM})\end{array}$ & $\begin{array}{l}{[\mathrm{FeS}]} \\
(\mathrm{mM})\end{array}$ & $\mathrm{pH}$ & $\begin{array}{c}\mathrm{DO} \\
\left(\mathrm{mg} \cdot \mathrm{L}^{-1}\right)\end{array}$ & $\begin{array}{l}\mathrm{DIC}^{a} \\
(\mathrm{mM})\end{array}$ & $\begin{array}{l}\text { flow rate } \\
\left(\mathrm{mL} \cdot \mathrm{min}^{-1}\right)\end{array}$ & $\begin{array}{l}{[\mathrm{U}]_{\mathrm{ss}}{ }^{b}} \\
(\mu \mathrm{M})\end{array}$ & $\begin{array}{c}R_{\mathrm{n}} \times 10^{-6} \\
\left(\mathrm{~mol} \mathrm{U} \cdot \mathrm{mol} \mathrm{U}(\mathrm{IV})^{-1} \cdot \mathrm{s}^{-1}\right)\end{array}$ \\
\hline \multicolumn{9}{|c|}{ variation of carbonate } \\
\hline 1a & 0.46 & 4.8 & 7.0 & 1.8 & 10.8 & 1.89 & 1 & $25.5 \pm 4.14$ \\
\hline $1 b$ & 0.47 & 4.8 & 7.0 & 1.8 & 10.8 & 1.83 & 1 & $23.8 \pm 3.86$ \\
\hline 2 & 0.47 & 4.8 & 7.0 & 1.8 & 0.97 & 1.86 & $\backslash$ & $13.7 \pm 1.84$ \\
\hline $3 a$ & 0.47 & 4.8 & 7.0 & 1.8 & 0 & 1.88 & 0.12 & $0.16 \pm 0.01$ \\
\hline $3 b$ & 0.47 & 4.8 & 7.0 & 1.8 & 0 & 1.81 & 0.10 & $0.13 \pm 0.01$ \\
\hline 4 & 0.46 & 1 & 7.0 & 1.8 & 10.8 & 1.84 & 8.63 & $11.5 \pm 0.23$ \\
\hline 5 & 0.47 & 1 & 7.0 & 1.8 & 0.97 & 1.81 & 5.93 & $7.61 \pm 0.17$ \\
\hline 6 & 0.47 & 1 & 7.0 & 1.8 & 0 & 1.81 & 1.25 & $1.66 \pm 0.06$ \\
\hline \multicolumn{9}{|c|}{ variation of $\mathrm{DO}$} \\
\hline 7 & 0.48 & 4.8 & 7.0 & $<0.1$ & 10.8 & 1.83 & 0.076 & $0.099 \pm 0.004$ \\
\hline 8 & 0.46 & $\backslash$ & 7.0 & $<0.1$ & 10.8 & 1.91 & 1.42 & $1.96 \pm 0.05$ \\
\hline \multicolumn{9}{|c|}{ variation of $\mathrm{pH}$} \\
\hline 9 & 0.47 & 4.8 & 5.4 & 1.8 & 1.8 & 1.90 & $\backslash$ & $2.30 \pm 0.21$ \\
\hline 10 & 0.47 & 4.8 & 9.0 & 1.8 & 1.0 & 1.88 & $\backslash$ & $22.1 \pm 3.31$ \\
\hline 11 & 0.47 & 1 & 5.4 & 1.8 & 1.8 & 1.91 & 6.41 & $8.88 \pm 0.42$ \\
\hline \multicolumn{9}{|c|}{ variation of $\mathrm{Fe}(\mathrm{III})$ oxides } \\
\hline 12 & 0.45 & Goe. & 7.0 & 1.8 & 10.8 & 1.96 & 9.06 & $12.3 \pm 0.32$ \\
\hline 13 & 0.51 & Ferri. & 7.0 & 1.8 & 10.8 & 1.84 & 11.4 & $14.7 \pm 0.65$ \\
\hline
\end{tabular}

${ }^{a}$ Dissolved inorganic carbon (DIC) calculated from Visual MINTEQ at equilibrium with $\mathrm{CO}_{2}$ gas mix used (Table S2). ${ }^{b}$ When steady-state oxidation of noncrystalline $\mathrm{U}(\mathrm{IV})$ was observed, eq 1 was used to calculate the corresponding oxidation rate.

concentration varied by less than $10 \%$. Over 40 residence times (equivalent to $\sim 18 \mathrm{~h}$ ) in such a flow-through experiment, usually less than $40 \%$ of total noncrystalline U(IV) was oxidized and dissolved. The mass concentration of noncrystalline U(IV) at steady-state oxidation was then adjusted for the loss of $U$ from the reactor in rate calculations.

\section{RESULTS AND DISCUSSION}

FeS Failure to Inhibit the Rapid Oxidation of Noncrystalline U(IV) in the Presence of Carbonate. The oxidation of noncrystalline $\mathrm{U}(\mathrm{IV})$ was examined in the presence of $4.8 \mathrm{mM} \mathrm{FeS}$ under varied total carbonate concentration ranging from 0 to $10.8 \mathrm{mM}$. Contrary to the expectation that $\mathrm{FeS}$ would effectively consume oxygen and inhibit noncrystalline U(IV) oxidation, dissolved U rapidly increased upon the introduction of an oxic solution to the CSTR (Figure 1a). The oxidation of noncrystalline U(IV) showed a clear dependence on total dissolved carbonate (DIC) concentration of the influent. With $10.8 \mathrm{mM} \mathrm{DIC}$, total dissolved $\mathrm{U}$ concentration peaked at $\sim 25 \mu \mathrm{M}$ within 13 residence times $(\tau)$ (equivalent to $\sim 5 \mathrm{~h}$ ). A lower peak value of $\sim 14 \mu \mathrm{M}$ occurred at a DIC concentration of $0.97 \mathrm{mM}$. In the absence of carbonate, a much slower oxidation of noncrystalline $\mathrm{U}(\mathrm{IV})$ was observed throughout the course of the experiment, where the dissolved $U$ concentration remained less than 0.3 $\mu \mathrm{M}$. The calculated oxidation rate of noncrystalline $\mathrm{U}(\mathrm{IV})$ dropped considerably from $25 \times 10^{-6}$ to $\sim 0.15 \times 10^{-6}$ (mol. $\mathrm{mol} \mathrm{U}(\mathrm{IV})^{-1} \cdot \mathrm{s}^{-1}$ ) as DIC concentration decreased from 10.8 $\mathrm{mM}$ to $0 \mathrm{mM}$ (Table 1$)$. In contrast, DO concentration profiles followed a similar trend at different DIC concentrations despite the discrepancy in the oxidation of biomass-associated noncrystalline U(IV). The effluent DO concentrations steadily increased after $20 \tau$ in all experiments until the influent level $\left(\sim 1.8 \mathrm{mg} \cdot \mathrm{L}^{-1}\right)$ was reached after a brief stagnancy at $\sim 0.5 \mathrm{mg}$. $\mathrm{L}^{-1}$. Evidently, although $\mathrm{FeS}$ was able to remove DO in the suspension, the mobilization of $U$ was not inhibited by its presence. The fast release of $U$ was not captured by effluent $\mathrm{Eh}$, which resembled the trend of DO (data not shown).

The lack of inhibition on U mobilization by FeS (Figure 1a) suggested that noncrystalline U(IV) can be easily oxidized by $\mathrm{DO}$ at low concentrations. The subsequent mobilization of oxidized $\mathrm{U}(\mathrm{VI})$ depended on carbonate concentration in the oxic solution. To examine the influence of oxygen and carbonate levels on the oxidation of noncrystalline U(IV), we conducted control experiments without $\mathrm{FeS}$ using influent solutions containing the same DO $\left(1.8 \mathrm{mg} \cdot \mathrm{L}^{-1}\right)$ and a range of carbonate concentration $(0-10.8 \mathrm{mM})$. Figure $1 \mathrm{~b}$ shows that a higher DIC concentration resulted in a greater release of dissolved $U$ to the effluent. However, the dramatic rise in $U$ concentration (Figure 1a) was not observed in any control experiment, even though the DO levels were higher than those in the presence of $\mathrm{FeS}$. Steady-state oxidation of noncrystalline $\mathrm{U}(\mathrm{IV})$ was quickly established at relatively low $\mathrm{U}$ concentrations. The steady-state $\mathrm{U}$ concentrations were then used to calculate the oxidation rates of noncrystalline $U(I V)$, which increased from 1.66 to $11.5 \times 10^{-6}\left(\mathrm{~mol} \cdot \mathrm{mol} \mathrm{U}(\mathrm{IV})^{-1} \cdot \mathrm{s}^{-1}\right)$ as DIC concentration rose. Compared with the rates in the presence of $\mathrm{FeS}$, noncrystalline U(IV) dissolved approximately $50 \%$ more slowly at high DIC concentrations $(>0.1 \mathrm{mM})$. At 0 $\mathrm{mM}$ DIC, however, the oxidation rate in the absence of FeS was $\sim 10$ times greater than that in the presence of FeS.

Although both DO and carbonate promoted the oxidation of noncrystalline U(IV), the U peak exhibited in Figure 1a cannot be explained solely by these two factors. FeS seems to play a critical but unexpected role in influencing $U$ mobilization upon oxygen intrusion. The results are noticeably different from the inhibited oxidative dissolution of $\mathrm{UO}_{2}$ by $\mathrm{FeS}$ as discussed in previous studies. ${ }^{22,23}$ The dissolution rate of synthetic $\mathrm{UO}_{2}$ is approximately an order of magnitude lower in the presence of FeS under similar conditions due to effective removal of oxygen (Figure 2). Extensive dissolution of $\mathrm{UO}_{2}$ occurred only when FeS was depleted and DO levels started to increase. ${ }^{25} \mathrm{FeS}$ was 


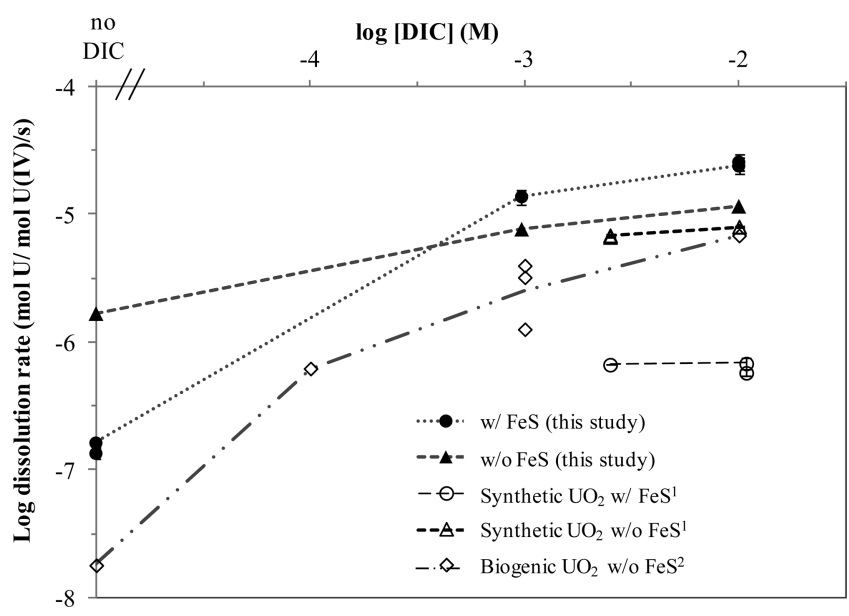

Figure 2. Log-mole-normalized oxidation rates $\left(\mathrm{mol} \cdot \mathrm{mol} \mathrm{U}(\mathrm{IV})^{-1} \cdot \mathrm{s}^{-1}\right.$ ) of noncrystalline $\mathrm{U}(\mathrm{IV})$ determined under moderately oxidizing conditions $\left(1.8 \mathrm{mg} \cdot \mathrm{L}^{-1} \mathrm{DO}\right)$ as a function of total DIC concentration in the presence and absence of $\mathrm{FeS}$ at $\mathrm{pH}$ 7.0. The rates are compared with previously reported values obtained from chemogenic ${ }^{23}$ and biogenic ${ }^{43} \mathrm{UO}_{2}$ particles under similar experimental conditions.

identified as an effective oxygen scavenger without the ability to enhance $U$ mobilization. The more rapid oxidation of noncrystalline $\mathrm{U}(\mathrm{IV})$ in the presence of FeS may be due to the catalytic role of oxidized $\mathrm{FeS}$ in facilitating electron transfer, as discussed in the sections below.

Figure 2 also demonstrates that the dissolution rate of $\mathrm{UO}_{2}$ is slower than that of noncrystalline U(IV) regardless of carbonate concentration under oxic conditions, which agrees with a previous batch study using an air-saturated solution. ${ }^{17}$ The difference in mobilization between the two reduced U(IV) species points to the inherent difference in reactivity between the species. Because of the absence of a crystalline structure, noncrystalline $\mathrm{U}(\mathrm{IV})$ seems susceptible to oxidation even at relatively low DO levels $\left(<0.5 \mathrm{mg} \cdot \mathrm{L}^{-1}\right)$. Importantly, dissolved carbonate promotes the oxidative mobilization of both reduced $\mathrm{U}(\mathrm{IV})$ species, ${ }^{25,31}$ suggesting that carbonate facilitates the release of $\mathrm{U}(\mathrm{VI})$ products to the bulk solution in similar manners.

Oxidation of Noncrystalline U(IV) by Oxidized FeS. In previous studies, $\mathrm{FeS}$ was identified as an oxygen scavenger and reductant for $\mathrm{U}(\mathrm{VI})$ to inhibit the dissolution of crystalline $\mathrm{UO}_{2}$ in oxic groundwater. ${ }^{21,23}$ The fast oxidation of noncrystalline $\mathrm{U}(\mathrm{IV})$ in the current study (Figure 1a), however, suggests a complex role of $\mathrm{FeS}$ in influencing $\mathrm{U}$ mobilization. To further elucidate its role, we conducted experiments under anoxic conditions in the presence and absence of FeS. The results (Figure S4) show that dissolved $U$ concentrations were significantly lower $(<0.1 \mu \mathrm{M})$ with $4.8 \mathrm{mM}$ FeS than the control $(\sim 1.3 \mu \mathrm{M})$ without FeS at steady state. Concomitantly, the oxidation rate of noncrystalline U(IV) decreased from 1.96 $\times 10^{-6}$ (without FeS) to $0.099 \times 10^{-6}\left(\mathrm{~mol} \cdot \mathrm{mol} \mathrm{U}(\mathrm{IV})^{-1} \cdot \mathrm{s}^{-1}\right)$ (with FeS), excluding the possibility that FeS intrinsically promoted $U$ mobilization (Table 1). The inhibitory effect of $\mathrm{FeS}$ under anoxic conditions may be attributed to the adsorption of dissolved U(IV) species to $\mathrm{FeS}$ particles, given the large surface areas provided by the disordered FeS. ${ }^{28,32}$ However, the inhibited mobilization of noncrystalline U(IV) cannot be sustained once $\mathrm{FeS}$ is oxidized by oxygen, particularly when the carbonate level is relatively high. Therefore, it is plausible that the oxidation products of $\mathrm{FeS}$ catalyzed the oxidative mobilization of noncrystalline $\mathrm{U}(\mathrm{IV})$, given $\mathrm{FeS}$ can transform to a range of redox reactive $\mathrm{Fe}(\mathrm{III})$ species after oxidation. $^{22,29}$

To examine the potential of $\mathrm{Fe}(\mathrm{III})$ species for oxidizing noncrystalline U(IV), we determined effluent Fe(II) concentrations from flow-through experiments in the presence of $\mathrm{FeS}$. As shown in previous studies, FeS dissolved under oxic conditions as a result of oxidative dissolution and preferential release of ferrous iron. ${ }^{33,34}$ Depending on the solution $\mathrm{pH}, \mathrm{FeS}$ oxidation also led to the formation of various $\mathrm{Fe}$ (III) (hydr)oxides, including ferrihydrite, goethite, lepidocrocite, and green rust. $^{22,29}$ If the $\mathrm{Fe}(\mathrm{III})$ species can react with noncrystalline U(IV), higher concentrations of dissolved Fe(II) would be generated relative to background $\mathrm{Fe}(\mathrm{II})$. With only $\mathrm{FeS}$ (Figure 3), a peak concentration for dissolved $\mathrm{Fe}(\mathrm{II})$ of

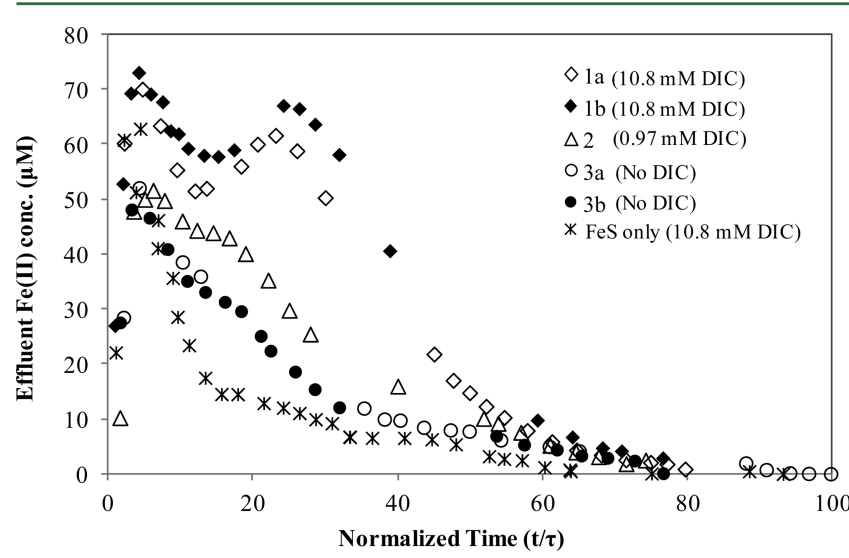

Figure 3. Release profiles of dissolved $\mathrm{Fe}$ (II) from $\mathrm{FeS}$ as a function of time at different influent carbonate concentrations in the presence and absence of noncrystalline U(IV). The experimental ID and corresponding carbonate concentrations are labeled. All influent solutions had a DO concentration of $1.8 \mathrm{mg} \cdot \mathrm{L}^{-1}$ and a $\mathrm{pH}$ of 7.0 . Replicates are represented by the filled vs open symbols.

$\sim 60 \mu \mathrm{M}$ was rapidly established after $\sim 5 \tau$, which then continuously decreased until complete $\mathrm{FeS}$ oxidation. This background $\mathrm{Fe}(\mathrm{II})$ profile agreed with previous studies at $\mathrm{pH}$ $7,^{23}$ showing a loss of $\sim 18 \%$ of total Fe(II) to the effluent. In the presence of noncrystalline U(IV), however, dissolved $\mathrm{Fe}(\mathrm{II})$ remained at a high concentration $(\sim 60 \mu \mathrm{M})$ for an additional $\sim 30 \tau$ after the peak at $\sim 6 \tau$ in $10.8 \mathrm{mM}$ DIC solution. By integrating the area below the $\mathrm{Fe}$ (II) profile, we estimated the total released $\mathrm{Fe}$ (II) during the course of oxidation to be $\sim 56 \%$ of total $\mathrm{Fe}$ (II) in $\mathrm{FeS}$. With a decreasing carbonate concentration, the amount decreased to $33 \%$ and $26 \%$ in 0.97 $\mathrm{mM}$ and $0 \mathrm{mM}$ DIC solutions, respectively. Clearly, more dissolved $\mathrm{Fe}$ (II) coincided with the greater oxidation rate of noncrystalline U(IV). The greater production of dissolved $\mathrm{Fe}$ (II) likely resulted from the reduction of $\mathrm{Fe}(\mathrm{III})$ by noncrystalline $\mathrm{U}(\mathrm{IV})$, although the specific $\mathrm{Fe}(\mathrm{III})$ phases remained to be characterized. This result points to the possibility of $\mathrm{Fe}(\mathrm{II})$ redox cycling during the oxidative mobilization of U(IV). Consistent with this notion, the redox couples of $\mathrm{U}(\mathrm{IV}) / \mathrm{U}(\mathrm{VI})$ and $\mathrm{Fe}(\mathrm{II}) / \mathrm{Fe}(\mathrm{III})$ (hydr)oxide have similar electrode potentials under common groundwater conditions. $^{26,35}$ Although the geochemical conditions did not favor $\mathrm{UO}_{2}$ oxidation in a previous study, ${ }^{25}$ biomass-associated noncrystalline U(IV) in molecular forms may be susceptible to oxidation by $\mathrm{Fe}$ (III) species. Given these results, this study provides compelling causative evidence that $\mathrm{Fe}(\mathrm{III})$ products 
from FeS oxidation can play a significant role in oxidizing and mobilizing the bioreduced form of $U$ during redox transitions.

Under acidic $\mathrm{pH}, \mathrm{FeS}$ was substantially dissolved to generate more dissolved $\mathrm{Fe}(\mathrm{II})$ in effluent. The proton-promoted solution-phase oxidation of $\mathrm{FeS}$ at $\mathrm{pH} 5.4$ resulted in a release of over $85 \%$ of total $\mathrm{Fe}$ and minor $\mathrm{Fe}$ (III) formation in the CSTR (Figure S5). This different FeS oxidation pathway also affected the oxidation of noncrystalline U(IV). Without exhibiting a high peak concentration, dissolved $\mathrm{U}(\mathrm{VI})$ remained relatively low $(\sim 1.6 \mu \mathrm{M})$ for $30 \tau$ (Figure S6). Even after oxygen breakthrough at $\sim 60 \tau$, the $\mathrm{U}$ concentration never exceeded $5 \mu \mathrm{M}$. In contrast, the experiment conducted at $\mathrm{pH} 9$ showed a similar trend of $U$ mobilization as in Figure 1, where significant release of $U$ occurred immediately after oxygen introduction. The results suggest that oxidative mobilization of noncrystalline U(IV) may strongly depend on Fe solid-phase species produced from $\mathrm{FeS}$ oxidation. Only solid-associated $\mathrm{Fe}$ (III) species (i.e., bulk or surface-adsorbed Fe(III)) may act as effective oxidants for noncrystalline U(IV). However, it should be noted that neither aged $\mathrm{Fe}(\mathrm{III})$ products nor synthetic 2-line ferrihydrite solids has a comparable reactivity as freshly oxidized FeS for mobilizing noncrystalline U(IV) under the same flow-through experimental conditions (Figure S7). In both experiments, $U$ mobilization exhibited a steady-state profile, similar to the control experiment in the absence of $\mathrm{Fe}$ solids. Therefore, the reactive $\mathrm{Fe}$ (III) species capable of oxidizing noncrystalline U(IV) was probably an intermediate $\mathrm{Fe}$ (III) produced at the early stage of $\mathrm{FeS}$ oxidation.

Characterization of $U$ and Fe Species during Oxidation. To elucidate the mechanism for the promoted oxidative mobilization of noncrystalline U(IV) by FeS, we conducted XPS analyses on solid samples collected within the initial $15 \tau$ of flow-through experiments at $\mathrm{pH} 7$ (Table 2).

Table 2. U 4f XPS Fitting Parameters and Relative Concentrations of $\mathrm{U}(\mathrm{IV}), \mathrm{U}(\mathrm{V})$, and $\mathrm{U}(\mathrm{VI})$ Components Determined by XPS on Selected Flow-through Experimental Samples Containing Biomass-Associated Noncrystalline U(IV)

\begin{tabular}{|c|c|c|c|c|c|}
\hline $\begin{array}{l}\text { reaction time } \\
\qquad(\mathrm{t} / \tau)\end{array}$ & $\begin{array}{c}\text { peak } \mathrm{U}(\mathrm{IV}) 4 \mathrm{f}_{7 / 2} \\
(\mathrm{eV})\end{array}$ & fwhm $^{a}$ & $\begin{array}{c}\mathrm{U}(\mathrm{IV}) \\
(\%)\end{array}$ & $\begin{array}{l}\mathrm{U}(\mathrm{V}) \\
(\%)\end{array}$ & $\begin{array}{l}\mathrm{U}(\mathrm{VI}) \\
(\%)\end{array}$ \\
\hline \multicolumn{6}{|c|}{ experiment no. 1 with $10.8 \mathrm{mM}$ DIC and $4.8 \mathrm{mM} \mathrm{FeS}$} \\
\hline 0 & 379.8 & 1.67 & 88 & 2 & 10 \\
\hline 5 & 379.6 & 1.98 & 17 & 9 & 74 \\
\hline 13 & 379.9 & 1.89 & 68 & 7 & 25 \\
\hline \multicolumn{6}{|c|}{ experiment no. 3 with $0 \mathrm{mM}$ DIC and $4.8 \mathrm{mM} \mathrm{FeS}$} \\
\hline 5 & 379.8 & 2.25 & 26 & 0 & 74 \\
\hline 15 & 379.9 & 2.42 & 67 & 9 & 24 \\
\hline \multicolumn{6}{|c|}{ experiment no. 4 with $10.8 \mathrm{mM} \mathrm{DIC,} \mathrm{no} \mathrm{FeS}$} \\
\hline 6 & 379.8 & 1.69 & 89 & 2 & 9 \\
\hline
\end{tabular}

${ }^{a}$ Full width at half-maximum of fitted $U$ components on $U$ 4f XPS spectra. All three $U$ components are constrained to have the same fwhm in a spectrum.

Detailed characterization with XPS provided a direct investigation on the oxidation states of $\mathrm{Fe}$ and $\mathrm{U}$ at or near surface of solid mixtures. Because noncrystalline $\mathrm{U}(\mathrm{IV})$ is essentially biomass-associated U(IV) without crystal structure, the $U$ components determined by XPS indicate the overall $U$ speciation. Before oxidation was initiated, the noncrystalline $\mathrm{U}(\mathrm{IV})$ consisted of a small but measurable U(VI) component $(\sim 10 \%)$ (Figure $4 \mathrm{a})$, partly due to inadvertent exposure to oxygen during sample handling and analysis. Shortly after oxidation began $(\sim 5 \tau)$, the $\mathrm{U}(\mathrm{VI})$ component dramatically increased in relative concentration in the presence of $\mathrm{FeS}$, accounting for $\sim 74 \%$ of total U. The binding energy (BE) of the $\mathrm{U}(\mathrm{VI}) 4 \mathrm{f}_{7 / 2}$ peak shifted from $381.6 \mathrm{eV}$ to a higher value of $382.7 \mathrm{eV}$, greater than previously reported values for $\mathrm{U}(\mathrm{VI})$ solids. ${ }^{36}$ The $\mathrm{U}(\mathrm{VI})$ species produced by noncrystalline U(IV) oxidation may not represent the known crystalline $U(V I)$ phases but rather labile U(VI)-carbonate complexes, which would explain the fast release of soluble $U$ in the presence of $10.8 \mathrm{mM}$ DIC. Surprisingly, the U(VI) species quickly diminished, dropping to merely $\sim 24 \%$ by $13 \tau$ when the dissolved U concentration reached its peak value (Figure 1a). The $U$ species appeared to be restored to a reduced form by releasing oxidized $\mathrm{U}(\mathrm{VI})$ to the effluent. After this time point, dissolved U(VI) continued to decrease until noncrystalline $\mathrm{U}(\mathrm{IV})$ was depleted from the CSTR. In all U $4 \mathrm{f}$ XPS spectra, a peak featuring $\mathrm{N} 1 \mathrm{~s}$ remained, suggesting a close association of noncrystalline $\mathrm{U}(\mathrm{IV})$ with biomass-related $\mathrm{N}$ compounds.

Corresponding to the $\mathrm{U}(\mathrm{VI})$ dominance at $\sim 5 \tau$, the FeS surface was significantly oxidized for a brief period. The characteristic $\mathrm{Fe}(\mathrm{II})-\mathrm{S}$ component at $206.9 \mathrm{eV}$ on $\mathrm{Fe} 2 \mathrm{p}_{3 / 2}$ $\mathrm{XPS}^{37}$ diminished from $34 \%$ to $13 \%$ of the initial FeS (Figure $4 \mathrm{~d}, \mathrm{e})$. In contrast, the multiplets of $\mathrm{Fe}(\mathrm{III})-\mathrm{S}$ components between 709 to $712 \mathrm{eV}$ increased drastically from $42 \%$ to $70 \%$ of total surface Fe components (Table S3). The full width at half-maximum (fwhm) for all $\mathrm{Fe}$ components in the oxidized sample also grew relative to those of the initial FeS, likely due to the more abundant high-spin surface $\mathrm{Fe}^{3+}$ species. ${ }^{38}$ This change in surface $\mathrm{Fe}$ species during the initial oxidation suggested either a rapid transformation of surface $\mathrm{Fe}$ (II) to $\mathrm{Fe}$ (III) species or a preferential loss of structural $\mathrm{Fe}$ (II) due to dissolution. Given that the dissolved $\mathrm{Fe}$ (II) concentration also peaked within $5 \tau$ (Figure 3 ), the preferential release of dissolved $\mathrm{Fe}$ (II) likely contributed to a $\mathrm{Fe}$ (III)-rich surface. As oxidation proceeded to $13 \tau$, the $\mathrm{Fe}(\mathrm{III})-\mathrm{S}$ components decreased in relative concentrations, along with growing $\mathrm{Fe}(\mathrm{II})-\mathrm{S}$ and $\mathrm{Fe}$ (II)-O components. Therefore, surface characterization of both $\mathrm{U}$ 4f and $\mathrm{Fe} 2 \mathrm{p}_{3 / 2}$ identified substantially oxidized surface species at an early stage of oxidation. The mobilization of noncrystalline U(IV) probably resulted from its oxidation by the transient surface $\mathrm{Fe}(\mathrm{III})$ species that were in close contact with U(IV) in the completely mixed reactor. Without $\mathrm{FeS}$ and its oxidation products, $\mathrm{U}$ components fit by XPS (Figure S8a) remained identical to the initial material at $6 \tau$ in the control experiment. The U(IV)dominated species suggests an effective removal of $\mathrm{U}(\mathrm{VI})$ to bulk solution facilitated by carbonate during oxidation by oxygen in the absence of FeS. Compared with DO, the surface $\mathrm{Fe}$ (III) species are perhaps better catalyst to facilitate electron transfer, causing rapid $\mathrm{U}(\mathrm{VI})$ accumulation before newly formed U(VI)-carbonate complexes can be removed from the biomass.

In the absence of carbonate, the oxidation of noncrystalline $\mathrm{U}(\mathrm{IV})$ appeared to be inhibited by FeS, implying a lack of $\mathrm{U}$ oxidation (Figure 1). However, the U 4f XPS spectra (Figure $\mathrm{S} 8 \mathrm{~b}$ ) indicated a $\mathrm{U}(\mathrm{VI})$ dominance at $\sim 5 \tau$, similar to the result in the presence of $10.8 \mathrm{mM}$ DIC. The U(VI) proportion then decreased to $24 \%$ by $15 \tau$, although only $<1 \%$ of total $U$ had been released into effluent. The characterization of surface $\mathrm{Fe}$ by XPS (not shown) agreed with those observed in Figure 4, suggesting that the formation of $\mathrm{Fe}$ (III)-rich surface was independent of carbonate concentration in solution. Therefore, 


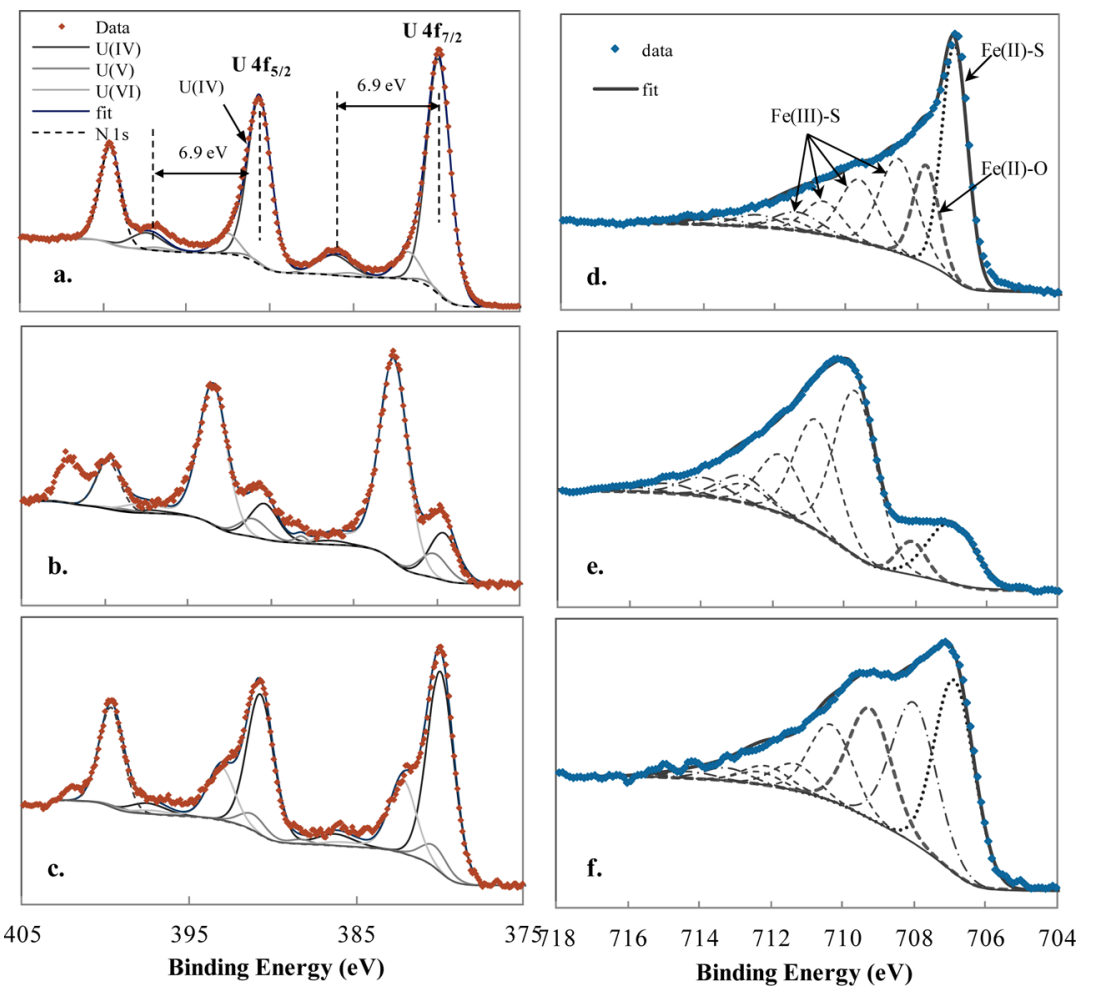

Figure 4. Narrow scans of $\mathrm{U} 4 \mathrm{f}(\mathrm{a}, \mathrm{b}, \mathrm{c})$ and $\mathrm{Fe} 2 \mathrm{p}_{3 / 2}(\mathrm{~d}, \mathrm{e}, \mathrm{f})$ XPS spectra of solid samples collected as a function of time from flow-through experiment using $0.47 \mathrm{mM}$ noncrystalline U(IV) and $4.8 \mathrm{mM} \mathrm{FeS}$. (a) and (d): Initial materials before the start of oxidation; (b) and (e): $5 \tau$ in experiment 1a; (c) and (f): $13 \tau$. All experiments were carried out under influent DO of $1.8 \mathrm{mg} \cdot \mathrm{L}^{-1}$ and $10.8 \mathrm{mM}$ DIC artificial groundwater conditions. The dots and colored solid lines are the experimental data and the corresponding fits, respectively.

noncrystalline U(IV) can be quickly oxidized by an intermediate $\mathrm{Fe}(\mathrm{III})$ species regardless of influent carbonate. The high concentration of effluent dissolved U, however, was accomplished only when a rapid release of $\mathrm{U}(\mathrm{VI})$ carbonate species occurred following the oxidation.

Complexity of Fe(III) Catalyzed Mobilization of Noncrystalline $U(I V)$. The fast mobilization of noncrystalline $\mathrm{U}(\mathrm{IV})$ in this study identifies a transient Fe(III) species as a prominent oxidant for biomass-associated U(IV). The ferric iron is shown to be more effective than DO in extracting electrons from U(IV) and causing U(VI) accumulation over a short period of time. Stumm and co-workers have shown that electron-transfer reactions involving $\mathrm{Fe}$ (II) and $\mathrm{Fe}(\mathrm{III})$ are often accelerated as a results of specific adsorption of the metal cations to mineral surfaces. ${ }^{39}$ Although the nature of the $\mathrm{Fe}(\mathrm{III})$ species remains unclear, XPS and flow-through results suggest that $\mathrm{Fe}(\mathrm{III})$ is likely bound to structural $\mathrm{S}(-\mathrm{II})$ on the $\mathrm{FeS}$ surface. After reacting with noncrystalline U(IV), the $>\mathrm{Fe}$ (III)$S$ species is reduced and released to the effluent as soluble $\mathrm{Fe}(\mathrm{II})$ (Figure 3). The fact that this Fe(III) species is shortlived and unsustainable over the oxidation of $\mathrm{FeS}$ possibly results from (1) the precipitation of less reactive $\mathrm{Fe}(\mathrm{III})$ (hydr)oxides solids, and (2) the formation of polysulfide and elemental sulfur. ${ }^{40}$ Under acidic $\mathrm{pH}$ conditions, the slow oxidation of noncrystalline U(IV) (Figure S5) further implies the complexity of geochemical conditions affecting $\mathrm{Fe}$ (III) speciation. One possible explanation is the lack of Fe(III) surface species at a $\mathrm{pH}$ of $\sim 5$ owing to the slow oxidation kinetics of dissolved $\mathrm{Fe}(\mathrm{II}) .^{41}$ The oxidation rate of noncrystalline $\mathrm{U}(\mathrm{IV})$ is limited relative to the control experiment in the absence of FeS (Table 1), likely because surface $\mathrm{Fe}(\mathrm{III})$ is absent or negligible, and DO levels are lowered by FeS consumption. Therefore, the $\mathrm{pH}$-dependent oxidation pathway of FeS has potentially an important impact on noncrystalline $\mathrm{U}(\mathrm{IV})$ oxidation. From neutral to basic $\mathrm{pH}$ values, the surfacemediated oxidation pathway becomes increasingly dominant, ${ }^{29}$ where structural $\mathrm{Fe}(\mathrm{II})$ in $\mathrm{FeS}$ is oxidized on solid surface without dissolving into the bulk solution. Although transitory, the reactive surface $\mathrm{Fe}(\mathrm{III})$ species may be more abundant at higher $\mathrm{pH}$, contributing to the faster release of $\mathrm{U}$ at a given carbonate concentration.

During the rapid oxidative mobilization of noncrystalline $\mathrm{U}(\mathrm{IV})$, soluble carbonate plays an critical role by forming stable complexes with $\mathrm{U}(\mathrm{VI})$ and facilitating the release of $\mathrm{U}(\mathrm{VI})$ from a biomass matrix, which includes cell membranes, lysed cellular material, and exopolymeric substances. Thus, the limited oxidation of noncrystalline U(IV) (Figure 1a) appears plausible once DIC is removed from the influent. In the absence of carbonate, oxidized $U$ cannot form highly soluble complexes, and it may be effectively adsorbed by $\mathrm{FeS}$ or remain bound to the biomass via chemical bonds with organic ligands. Intriguingly, oxidized $\mathrm{U}(\mathrm{VI})$ may even become reduced again by FeS after $5 \tau$ as suggested by the XPS result (Figure S8c). Given that more than $99 \%$ of $U$ remains solid-bound at $0 \mathrm{mM}$ DIC, the recovery of $\mathrm{U}(\mathrm{IV})$ implies that FeS acts as an effective reductant for surface-adsorbed and biomass-associated U(VI) upon slight oxidation. These results are also supported by previous reports showing that $\mathrm{FeS}$ reduced $\mathrm{U}(\mathrm{VI})$ to $\mathrm{U}(\mathrm{IV})$ species in the absence of carbonate. ${ }^{21,42}$ Until FeS depletion and oxygen breakthrough, the dissolved $U$ concentration is kept relatively low (Figure 1a), possibly due to readsorption of soluble $\mathrm{U}(\mathrm{VI})$ to $\mathrm{Fe}(\mathrm{III})$ (hydr)oxides generated from $\mathrm{FeS}$ oxidation. Overall, noncrystalline U(IV) has demonstrated a high susceptibility to oxidation in a FeS-containing system 
upon oxygen invasion, likely inherent to its molecular form and relatively weak association with biomass ligands. The eventual mobilization of $\mathrm{U}(\mathrm{VI})$, however, is caused by a combination of complexation, adsorption, and redox reactions, which are strongly influenced by the geochemical conditions (i.e., $\mathrm{pH}$, DIC, DO, etc.).

Environmental Implications. The long-term success of in situ biostimulated U(VI) immobilization relies on the stability of reduced U(IV) (i.e., noncrystalline $\mathrm{U}(\mathrm{IV})$ and uraninite) under redox fluctuating conditions, such as when oxygen reenters the active treatment zone. This study demonstrates that biomass-associated noncrystalline $\mathrm{U}(\mathrm{IV})$ is more readily oxidized than $\mathrm{UO}_{2}$ following oxygen intrusion under simulated groundwater conditions. While effectively consuming oxygen, $\mathrm{FeS}$ may indirectly accelerate $U$ mobilization through the formation of reactive intermediate $\mathrm{Fe}$ (III) surface species that promote electron transfer and oxidation of $\mathrm{U}(\mathrm{IV})$. The resulting $U$ mobilization is further promoted by the presence of carbonate, which forms stable complexes with U(VI) and facilitates the detachment from biomass. Because both iron sulfides and carbonate are commonly encountered in a groundwater system, the oxidative mobilization of bioreduced $\mathrm{U}(\mathrm{IV})$ species may occur at a faster rate than predicted on the basis of current oxidative dissolution studies and associated geochemical models assuming the sole existence of crystalline $\mathrm{UO}_{2}$. This vulnerability may also in part explain the "unexpectedly" fast remobilization of bioreduced U(IV) in sediment columns once electron donor additions are halted. ${ }^{12}$ Given the sparsity of thermodynamic and kinetic data on redox reactions of noncrystalline $\mathrm{U}(\mathrm{IV})$, more work is needed to evaluate the scale of its abundance and capture its lability in geochemical models. Whereas most recent studies focus on resolving $\mathrm{U}(\mathrm{IV})$ speciation, even less is known about the potential transformation of noncrystalline U(IV) species to more crystalline $\mathrm{UO}_{2}$. Conditions that favor the preferential formation of $\mathrm{UO}_{2}$ over noncrystalline $\mathrm{U}(\mathrm{IV})$ would allow a more effective inhibition of U(IV) oxidation by iron sulfides and prolonged $U$ immobilization in the event of occasional oxygen intrusion into reducing zones. Future research should examine the mechanisms of $U$ retention and rates of oxidative remobilization in natural sediments where $\mathrm{FeS}$ are produced with mixed U(IV) species.

\section{ASSOCIATED CONTENT}

\section{S Supporting Information}

The Supporting Information is available free of charge on the ACS Publications website at DOI: 10.1021/acs.est.5b04281.

Tables showing the WLP media composition (Table S1), artificial groundwater compositions (Table S2), and Fe 2p3/2 XPS fitting results (Table S3). Figures showing noncrystalline U(IV) characterization (Figure S1), flowthrough system schematic (Figure S2), cumulative U release for rate analysis (Figure S3), anoxic dissolution of noncrystalline U(IV) (Figure S4), final oxidation products (Figure S5), pH-dependent oxidation of noncrystalline U(IV) (Figure S6); effect of $\mathrm{Fe}(\mathrm{III})$ on $\mathrm{U}(\mathrm{IV}$ ) oxidation (Figure S7), and U 4f XPS spectra (Figure S8). (PDF)

\section{AUTHOR INFORMATION}

\section{Corresponding Author}

*Tel: (734) 764-8495; fax: (734) 763-2275; e-mail: ford@ umich.edu.

\section{Notes}

The authors declare no competing financial interest.

\section{ACKNOWLEDGMENTS}

The authors would like to thank Tom Yavaraski for his technical assistance in ICP-MS sample analysis. We also thank Young-Soo Han at the Korea Institute of Geoscience and Mineral Resources for her help with the XPS analysis. This research was supported by Subsurface Biogeochemical Research Program in the Office of Science (BER), U.S. Department of Energy, grant no. DE-FG02-09ER64803. Part of this research was carried out at SSRL, a Directorate of SLAC National Accelerator Laboratory and an Office of Science User Facility operated for the U.S. DOE by Stanford University. Work at EPFL was funded by grant no. 200020-144335 from the Swiss National Science Foundation.

\section{REFERENCES}

(1) Wall, J. D.; Krumholz, L. R. Uranium Reduction. Annu. Rev. Microbiol. 2006, 60 (1), 149-166.

(2) Lovley, D. R.; Phillips, E. J. P.; Gorby, Y. A.; Landa, E. R. Microbial reduction of uranium. Nature 1991, 350 (6317), 413-416.

(3) Abdelouas, A.; Lutze, W.; Gong, W.; Nuttall, E. H.; Strietelmeier, B. A.; Travis, B. J. Biological reduction of uranium in groundwater and subsurface soil. Sci. Total Environ. 2000, 250 (1-3), 21-35.

(4) Gu, B.; Wu, W.-M.; Ginder-Vogel, M. A.; Yan, H.; Fields, M. W.; Zhou, J.; Fendorf, S.; Criddle, C. S.; Jardine, P. M. Bioreduction of uranium in a contaminated soil column. Environ. Sci. Technol. 2005, 39 (13), 4841-4847.

(5) Lovley, D. R.; Roden, E. E.; Phillips, E. J. P.; Woodward, J. C. Enzymatic iron and uranium reduction by sulfate-reducing bacteria. Mar. Geol. 1993, 113 (1-2), 41-53.

(6) Bargar, J. R.; Bernier-Latmani, R.; Giammar, D. E.; Tebo, B. M. Biogenic uraninite nanoparticles and their importance for uranium remediation. Elements 2008, 4 (6), 407-412.

(7) Bernier-Latmani, R.; Veeramani, H.; Vecchia, E. D.; Junier, P.; Lezama-Pacheco, J. S.; Suvorova, E. I.; Sharp, J. O.; Wigginton, N. S.; Bargar, J. R. Non-uraninite products of microbial U(VI) reduction. Environ. Sci. Technol. 2010, 44 (24), 9456-9462.

(8) Veeramani, H.; Alessi, D. S.; Suvorova, E. I.; Lezama-Pacheco, J. S.; Stubbs, J. E.; Sharp, J. O.; Dippon, U.; Kappler, A.; Bargar, J. R.; Bernier-Latmani, R. Products of abiotic U(VI) reduction by biogenic magnetite and vivianite. Geochim. Cosmochim. Acta 2011, 75 (9), 2512-2528.

(9) Fletcher, K. E.; Boyanov, M. I.; Thomas, S. H.; Wu, Q. Z.; Kemner, K. M.; Loffler, F. E. U(VI) reduction to mononuclear U(IV) by desulfitobacterium species. Environ. Sci. Technol. 2010, 44 (12), 4705-4709.

(10) Boyanov, M. I.; Fletcher, K. E.; Kwon, M. J.; Rui, X.; O’Loughlin, E. J.; Löffler, F. E.; Kemner, K. M. Solution and microbial controls on the formation of reduced U(IV) species. Environ. Sci. Technol. 2011, 45 (19), 8336-8344.

(11) Bargar, J. R.; Williams, K. H.; Campbell, K. M.; Long, P. E.; Stubbs, J. E.; Suvorova, E. I.; Lezama-Pacheco, J. S.; Alessi, D. S.; Stylo, M.; Webb, S. M.; Davis, J. A.; Giammar, D. E.; Blue, L. Y.; BernierLatmani, R. Uranium redox transition pathways in acetate-amended sediments. Proc. Natl. Acad. Sci. U. S. A. 2013, 110 (12), 4506-4511.

(12) Sharp, J. O.; Lezama-Pacheco, J. S.; Schofield, E. J.; Junier, P.; Ulrich, K.-U.; Chinni, S.; Veeramani, H.; Margot-Roquier, C.; Webb, S. M.; Tebo, B. M.; Giammar, D. E.; Bargar, J. R.; Bernier-Latmani, R. Uranium speciation and stability after reductive immobilization in 
aquifer sediments. Geochim. Cosmochim. Acta 2011, 75 (21), 64976510.

(13) Wang, Y. H.; Frutschi, M.; Suvorova, E.; Phrommavanh, V.; Descostes, M.; Osman, A. A. A.; Geipel, G.; Bernier-Latmani, R. Mobile uranium(IV)-bearing colloids in a mining-impacted wetland. Nat. Commun. 2013, 4, 2942.

(14) Alessi, D. S.; Lezama-Pacheco, J. S.; Janot, N.; Suvorova, E. I.; Cerrato, J. M.; Giammar, D. E.; Davis, J. A.; Fox, P. M.; Williams, K. H.; Long, P. E.; Handley, K. M.; Bernier-Latmani, R.; Bargar, J. R. Speciation and reactivity of uranium products formed during in situ bioremediation in a shallow alluvial aquifer. Environ. Sci. Technol. 2014, 48 (21), 12842-12850.

(15) Alessi, D. S.; Lezama-Pacheco, J. S.; Stubbs, J. E.; Janousch, M.; Bargar, J. R.; Persson, P.; Bernier-Latmani, R. The product of microbial uranium reduction includes multiple species with $\mathrm{U}(\mathrm{IV})$-phosphate coordination. Geochim. Cosmochim. Acta 2014, 131, 115-127.

(16) Alessi, D. S.; Uster, B.; Veeramani, H.; Suvorova, E. I.; LezamaPacheco, J. S.; Stubbs, J. E.; Bargar, J. R.; Bernier-Latmani, R. Quantitative Separation of Monomeric U(IV) from UO2 in Products of U(VI) Reduction. Environ. Sci. Technol. 2012, 46 (11), 6150-6157.

(17) Cerrato, J. M.; Ashner, M. N.; Alessi, D. S.; Lezama-Pacheco, J. S.; Bernier-Latmani, R.; Bargar, J. R.; Giammar, D. E. Relative reactivity of biogenic and chemogenic uraninite and biogenic noncrystalline U(IV). Environ. Sci. Technol. 2013, 47 (17), 9756-9763.

(18) Abdelouas, A.; Lutze, W.; Nuttall, E. Chemical durability of uraninite precipitated on Navajo sandstone. C. R. Acad. Sci., Ser. IIa: Sci. Terre Planetes 1998, 327 (2), 101-106.

(19) Moon, H. S.; Komlos, J.; Jaffé, P. R. Biogenic U(IV) oxidation by dissolved oxygen and nitrate in sediment after prolonged $\mathrm{U}(\mathrm{VI})$ / $\mathrm{Fe}(\mathrm{III}) / \mathrm{SO}_{4}{ }^{2-}$ reduction. J. Contam. Hydrol. 2009, 105 (1-2), 18-27.

(20) Hua, B.; Deng, B. L. Reductive immobilization of uranium(VI) by amorphous iron sulfide. Environ. Sci. Technol. 2008, 42 (23), 87038708.

(21) Hyun, S. P.; Davis, J. A.; Sun, K.; Hayes, K. F. Uranium(VI) reduction by iron(II) monosulfide mackinawite. Environ. Sci. Technol. 2012, 46 (6), 3369-3376.

(22) Bi, Y.; Hyun, S. P.; Kukkadapu, R. K.; Hayes, K. F. Oxidative dissolution of $\mathrm{UO}_{2}$ in a simulated groundwater containing synthetic nanocrystalline mackinawite. Geochim. Cosmochim. Acta 2013, 102 (0), 175-190.

(23) Bi, Y.; Hayes, K. F. Nano-FeS inhibits $\mathrm{UO}_{2}$ reoxidation under varied oxic conditions. Environ. Sci. Technol. 2013, 48 (1), 632-640.

(24) Suzuki, Y.; Kelly, S. D.; Kemner, K. M.; Banfield, J. F. Direct microbial reduction and subsequent preservation of uranium in natural near-surface sediment. Appl. Environ. Microbiol. 2005, 71 (4), 17901797.

(25) Bi, Y.; Hayes, K. F. Surface passivation limited $\mathrm{UO}_{2}$ oxidative dissolution in the presence of FeS. Environ. Sci. Technol. 2014, 48 (22), 13402-13411.

(26) Ginder-Vogel, M.; Stewart, B.; Fendorf, S. Kinetic and mechanistic constraints on the oxidation of biogenic uraninite by ferrihydrite. Environ. Sci. Technol. 2010, 44 (1), 163-169.

(27) Sani, R. K.; Peyton, B. M.; Dohnalkova, A.; Amonette, J. E. Reoxidation of reduced uranium with iron(III) (hydr)oxides under sulfate-reducing conditions. Environ. Sci. Technol. 2005, 39 (7), 20592066.

(28) Jeong, H. Y.; Lee, J. H.; Hayes, K. F. Characterization of synthetic nanocrystalline mackinawite: Crystal structure, particle size, and specific surface area. Geochim. Cosmochim. Acta 2008, 72 (2), 493-505.

(29) Jeong, H. Y.; Han, Y. S.; Park, S. W.; Hayes, K. F. Aerobic oxidation of mackinawite $(\mathrm{FeS})$ and its environmental implication for arsenic mobilization. Geochim. Cosmochim. Acta 2010, 74 (11), 31823198.

(30) Schwertmann, U.; Cornell, R. M. Iron Oxides in the Laboratory: Preparation and Characterization, 2nd ed.; Wiley-VCH: Weinheim ; New York, 2000; pp 1-188.

(31) Pablo, J. D.; Casas, I.; Gimenez, J.; Molera, M.; Rovira, M.; Duro, L.; Bruno, J. The oxidative dissolution mechanism of uranium dioxide. I. The effect of temperature in hydrogen carbonate medium. Geochim. Cosmochim. Acta 1999, 63 (19-20), 3097-3103.

(32) Wolthers, M.; Charlet, L.; Van der Linde, P. R.; Rickard, D.; Van der Weijden, C. H. Surface chemistry of disordered mackinawite (FeS). Geochim. Cosmochim. Acta 2005, 69 (14), 3469-3481.

(33) Mikhlin, Y. Disordered surface layers of metal sulfides and their reactivity. Glass Phys. Chem. 2007, 33 (4), 402-410.

(34) Mikhlin, Y.; Varnek, V.; Asanov, I.; Tomashevich, Y.; Okotrub, A.; Livshits, A.; Selyutin, G.; Pashkov, G. Reactivity of pyrrhotite (Fe9S10) surfaces: Spectroscopic studies. Phys. Chem. Chem. Phys. 2000, 2 (19), 4393-4398.

(35) Ginder-Vogel, M.; Fendorf, S. Chapter 11: Biogeochemical Uranium Redox Transformations: Potential Oxidants of Uraninite. In Developments in Earth and Environmental Sciences; Mark, O. B.; Douglas, B. K., Eds. Elsevier: Amsterdam, Netherlands, 2007; Vol. 7, pp 293-319.

(36) Ilton, E. S.; Bagus, P. S. XPS determination of uranium oxidation states. Surf. Interface Anal. 2011, 43 (13), 1549-1560.

(37) Mullet, M.; Boursiquot, S.; Abdelmoula, M.; Genin, J. M.; Ehrhardt, J. J. Surface chemistry and structural properties of mackinawite prepared by reaction of sulfide ions with metallic iron. Geochim. Cosmochim. Acta 2002, 66 (5), 829-836.

(38) Grosvenor, A. P.; Kobe, B. A.; Biesinger, M. C.; McIntyre, N. S. Investigation of multiplet splitting of Fe 2p XPS spectra and bonding in iron compounds. Surf. Interface Anal. 2004, 36 (12), 1564-1574.

(39) Wehrli, B.; Sulzberger, B.; Stumm, W. Redox processes catalyzed by hydrous oxide surfaces. Chem. Geol. 1989, 78 (3-4), 167-179.

(40) Chirita, P. Iron monosulfide (FeS) oxidation by dissolved oxygen: characteristics of the product layer. Surf. Interface Anal. 2009, 41 (5), 405-411.

(41) Stumm, W.; Lee, G. F. Oxygenation of Ferrous Iron. Ind. Eng. Chem. 1961, 53 (2), 143-146.

(42) Veeramani, H.; Scheinost, A. C.; Monsegue, N.; Qafoku, N. P.; Kukkadapu, R.; Newville, M.; Lanzirotti, A.; Pruden, A.; Murayama, M.; Hochella, M. F. Abiotic reductive immobilization of U(VI) by biogenic mackinawite. Environ. Sci. Technol. 2013, 47 (5), 2361-2369.

(43) Ulrich, K. U.; Ilton, E. S.; Veeramani, H.; Sharp, J. O.; BernierLatmani, R.; Schofield, E. J.; Bargar, J. R.; Giammar, D. E. Comparative dissolution kinetics of biogenic and chemogenic uraninite under oxidizing conditions in the presence of carbonate. Geochim. Cosmochim. Acta 2009, 73 (20), 6065-6083. 